\title{
Lineage, Arrangement, and Death of Clonally Related Motoneurons in Chick Spinal Cord
}

\author{
Steven M. Leber, ${ }^{1,2, a}$ S. Marc Breedlove, ${ }^{1, b}$ and Joshua R. Sanes' \\ 'Department of Anatomy and Neurobiology, Washington University School of Medicine, St. Louis, Missouri 63110, and \\ 2Division of Pediatric Neurology, St. Louis Children's Hospital, St. Louis, Missouri 63110
}

We have used recombinant retroviruses as lineage markers to study the genealogy of motoneurons (MNs) in the chick spinal cord. We infected individual progenitors by injecting virions into the neural tube at stages 11-18, a few cell divisions before MNs are born. The descendants of infected cells were subsequently detected with a histochemical stain for $\beta$-galactosidase (lacZ), the product of the retrovirally introduced gene. Clonally related, lacZ-positive cells formed clusters that were usually radial or planar in shape. The cells that comprised these clones were classified by morphology, size, and location. About $15 \%$ of the clones in the spinal cord contained MNs, and these were studied further.

Multicellular clones that contained only MNs were infrequent. Instead, close relatives of MNs included a variety of other neurons, as well as glia and ependymal cells. Most non-MNs in these clones were found in the ventral and intermediate parts of the spinal cord. Neurons included interneurons and autonomic preganglionic neurons in the column of Terni. Labeled glia were found in both the gray and white matter and included astrocytes and cells tentatively identified as oligodendrocytes. Thus, even shortly before MNs are born, their progenitors are multipotential.

Clonally related $\mathrm{MNs}$ were not restricted to a single motor pool. Some clones contained MNs in both the medial and lateral parts of the lateral motor column, which are known to innervate distinct groups of limb muscles. Furthermore, some clones contained MNs in the medial motor column (which innervate axial muscles) as well as in the lateral motor column. In contrast, the dispersal of clonally related MNs (and other neurons) was restricted in the rostrocaudal axis; most clones were less than one-quarter segment in length. Thus, MNs derived from a single progenitor are more likely to share rostrocaudal position than synaptic targets.

To investigate the fate of clonally related MNs, we counted the number of MNs per clone at times before, during, and

\footnotetext{
Received Jan. 18, 1990; revised Feb. 28, 1990; accepted March 12, 1990.

We thank Dorothy Dill, Robin Morris-Valero, and Jeanette Cunningham for their assistance and Grace Gray for helpful discussions. This research has been supported by NINDS Training Grant T32 NS07027 and by grants from the Muscular Dystrophy Association and the McKnight Foundation.

We dedicate this paper to Viktor Hamburger, our friend and colleague, on the occasion of his 90 th birthday.

Correspondence should be addressed to Dr. Joshua R. Sanes, Department of Anatomy and Neurobiology, Box 8108, Washington University School of Medicine, 660 South Euclid Ave., St. Louis, MO 63110.

- Present address: Division of Pediatric Neurology, The University of Michigan Medical Center, R6060 Kresge II, Box 0570, Ann Arbor, MI 48109-0570.

'Present address: Department of Psychology, University of California, Berkeley, Cᄉ 94720.

Copyright (C) 1990 Society for Neuroscience $0270-6474 / 90 / 072451-12 \$ 03.00 / 0$
}

after the major period of MN death. The number of MNs per clone declined in precise parallel with the total number of MNs during this period, suggesting that neurons are eliminated without regard to their clone of origin. This result implies that the decision to live or die occurs on a cell-by-cell rather than a clone-by-clone basis.

The spinal motoneuron (MN) is one of the most extensively studied cells in the developing nervous system. A wealth of information is available about its birth, differentiation, synaptic connectivity, dependence on extrinsic factors, and naturally occurring death (reviewed in Ramón y Cajal, 1960; Hamburger, 1977; Hollyday, 1980; Landmesser, 1980; Hamburger and Oppenheim, 1982; Altman and Bayer, 1984). In contrast, little is known about the progenitors from which MNs arise, and it has therefore been difficult to assess the degree to which an MN's lineage influences its fate. For example, if $\mathrm{MNs}$ arose from neuroepithelial precursors that produced only MNs, one might conclude that commitment to a motoneuronal fate occurs prior to the termination of mitosis. If not, it is important to know what other classes of cells arise from the precursors that generate MNs, and whether these cells bear particular spatial or functional relationships to the MNs. In either case, in that MNs are apparently prespecified to project along particular pathways and/ or to innervate particular muscles (Landmesser, 1988), one might ask whether progenitors produce MNs that are restricted to a single motor column, motor pool, or spinal segment. The existence of such restrictions would implicate lineage as one determinant of the synaptic identity of individual MNs. Finally, given that about half of the initially generated MNs die during normal development (Hamburger and Oppenheim, 1982), for reasons that are not yet completely understood (Oppenheim, 1989), it is interesting to consider whether an MN's ancestry affects its chances of survival.

The ability to address such issues has been hampered by the lack of suitable lineage markers. Recently, however, recombinant retroviruses have been used in a number of systems as stable, heritable markers that can label neural precursor cells at defined stages in vivo (reviewed in Sanes, 1989). These vectors were constructed by replacing viral structural genes with the Escherichia coli $\beta$-galactosidase gene (lacZ). They are capable of inserting the lac $Z$ gene into the genome of infected cells but are replication-incompetent and unable to infect neighboring cells. Therefore, only the progeny of infected cells express $\beta$-galactosidase (lacZ), which can be detected with a histochemical stain. Here, we have used this method to analyze the lineage of MNs in the chick spinal cord. Preliminary reports of this work have appeared elsewhere (Leber et al., 1989a, b). 

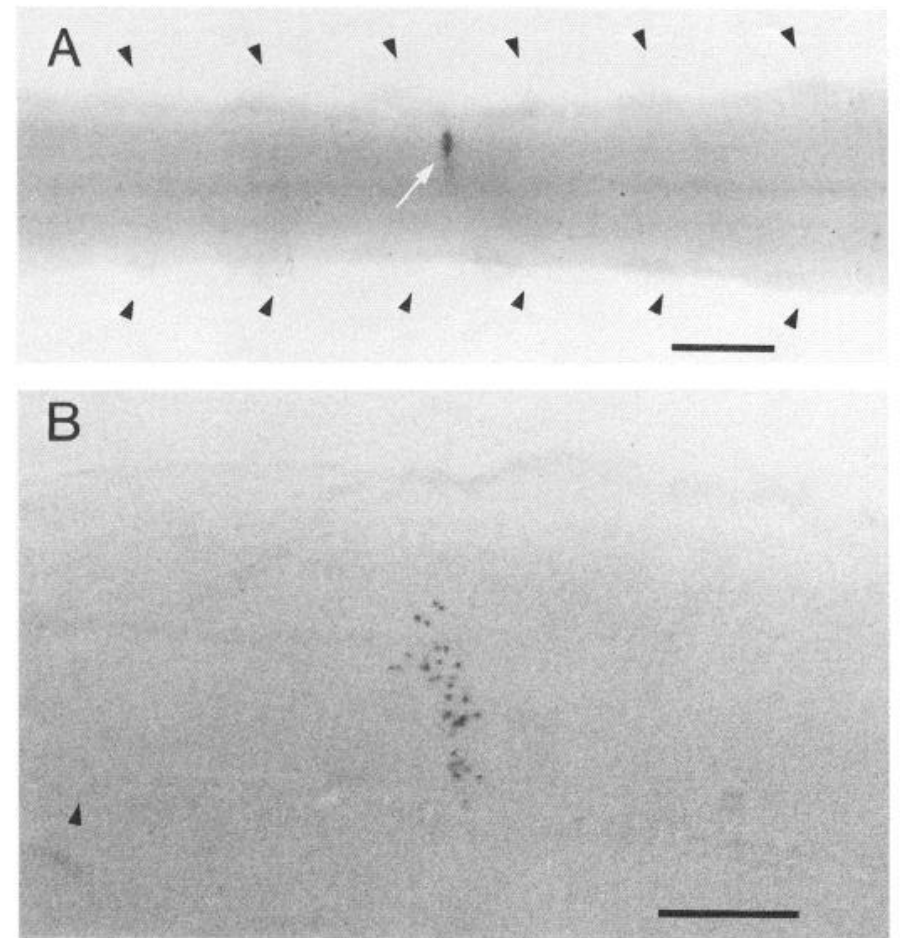

Figure 1. Clusters of labeled cells in whole mounts of lumbar spinal cord. The rostrocaudal dispersal of labeled cells was much less than the length of a spinal segment. $A$, Dorsal view of a stage 31 spinal cord from an embryo injected at stage 13. Positions of spinal roots are marked by arrowheads to show segment lengths. The white arrow marks the single cluster of lacZ-positive cells detected in this $4.5 \mathrm{~mm}$ length of spinal cord. Scale bar, $500 \mu \mathrm{m}$. $B$, Higher-magnification ventral view of a stage 41 spinal cord from an embryo injected at stage 17 . This clone spanned a longer rostrocaudal distance than average. The midline of the spinal cord is marked with an arrow. Scale bar, $250 \mu \mathrm{m}$.

\section{Materials and Methods}

Viruses. The 2 retroviral vectors used in this study have been described by Galileo et al. (1990). The first, LZ10, was constructed by substituting the $E$. coli lacZ gene for the $p o l$ and $e n v$ genes of a Rous sarcoma virus (RSV). LZ10 encodes a gag-lacZ fusion protein which accumulates in the cytoplasm of the progeny of infected cells. The second vector, LZ12, is a Moloney murine virus in which $l a c Z$ was fused to a nuclear localization sequence from the SV40 T antigen and placed under control of an RSV internal promoter. The LZ12 virions were packaged in the amphotropic helper cell line PA317 (Miller and Buttimore, 1986; obtained from American Type Culture Collection), enabling them to infect avian cells. Infection with LZ12 leads to nuclear rather than cytoplasmic localization of lacZ. Virus-producing cells were cultured, and virions were concentrated, tested for replication-competent virus (which was never found), and titered as described in Sanes et al. (1986) and Galileo et al. (1990). The titers of viral concentrates were $\sim 10^{6}$ active virions per $\mathrm{ml}$, as determined by infection of cultured fibroblasts.

Injections. White Leghorn chicken eggs (SPAFAS, Roanoke, IL) were incubated at $37-38^{\circ} \mathrm{C}$ and the embryos staged according to Hamburger and Hamilton (1951). Viral concentrate (2.5-25 $\mu \mathrm{l}$ of either LZ10, LZ12, or a mixture of the 2 ) was mixed with $2.5 \mu \mathrm{l}$ of Polybrene $(1 \mathrm{mg} / \mathrm{ml}$; Sigma) and $1 \mu \mathrm{l}$ of $1 \%$ Fast green and diluted to a final volume of 27.5 $\mu \mathrm{l}$ with Earle's 199 medium; 100-650 $\mathrm{nl}$ of this mixture (in most cases $10-100$ active virions) were pressure-injected into the lumen of the prospective spinal cord at stages 11-18. After topical application of ampicillin $(\sim 50 \mu \mathrm{l}$ of $50 \mathrm{mg} / \mathrm{ml})$, the eggs were sealed with tape and returned to the incubator.

Histology. Embryos were killed after a variable period of incubation. Embryos older than stage 30 were perfused with cold $0.4 \%$ glutaraldehyde and $2.0 \%$ formaldehyde in PBS $(150 \mathrm{~mm} \mathrm{NaCl}$ and $15 \mathrm{~mm} \mathrm{Na}$ phosphate, $\mathrm{pH}$ 7.3). Their spinal cords were removed and immersed in the same fixative for $1 \mathrm{hr}$. Younger embryos were fixed by immersion for $1 \mathrm{hr}$ but not perfused. After several rinses in PBS, the spinal cords were stained overnight for lacZ as detailed by Galileo et al. (1990), rinsed again in PBS, and refixed in $2.0 \%$ glutaraldehyde and $2.0 \%$ formaldehyde in PBS for at least $4 \mathrm{hr}$. The spinal cords were cleared in glycerol, which allowed visualization of stained cells, even if these cells were small, solitary, or deeply buried. The rostrocaudal spread of labeled cells within a cluster was measured using an ocular micrometer. Slices of spinal cord containing labeled cells were cut by hand, returned to PBS, dehydrated, embedded in Poly/Bed 812 (Polysciences), and sectioned in the transverse plane at $20 \mu \mathrm{m}$. Some sections were counterstained with basic fuchsin. After mounting with immersion oil, sections were viewed with bright-field, Nomarski, and/or phase contrast optics. The distribution of cells found within an MN-containing cluster was mapped using a drawing tube. Several sections were superimposed to produce 2-dimensional reconstructions of clones. Selected sections were then removed from the slides, resectioned at $1 \mu \mathrm{m}$, and lightly counterstained with toluidine blue.

Clonal analysis. Lineage analysis by the retroviral method depends on knowing that particular groups of lacZ-positive cells are descended from a single infected progenitor (Sanes et al., 1986; Sanes, 1989). We therefore wish to discuss this issue before presenting our results. In previous studies, the arrangement of lacZ-positive cells in widely spaced, coherent clusters has been used to argue that each cluster is a clone, and statistical analyses have supported this conclusion (Turner and Cepko, 1987; Gray et al., 1988; Luskin et al., 1988). When we examined whole, cleared spinal cords, we found that lacZ-positive cells were clustered in discrete groups separated from each other by many cluster widths of lacZ-negative cells (Fig. 1). Because few virions were injected into each
Figure 2. Timing of $\mathrm{MN}$ birth and death. The number of $\mathrm{MNs}$ in the brachial (- - - - - ) and lumbar $(\stackrel{-}{\longrightarrow})$ lateral columns is plotted as a function of stage and time of development. The data are from Hamburger (1975), Hollyday and Hamburger (1977), and Lanser and Fallon (1984).

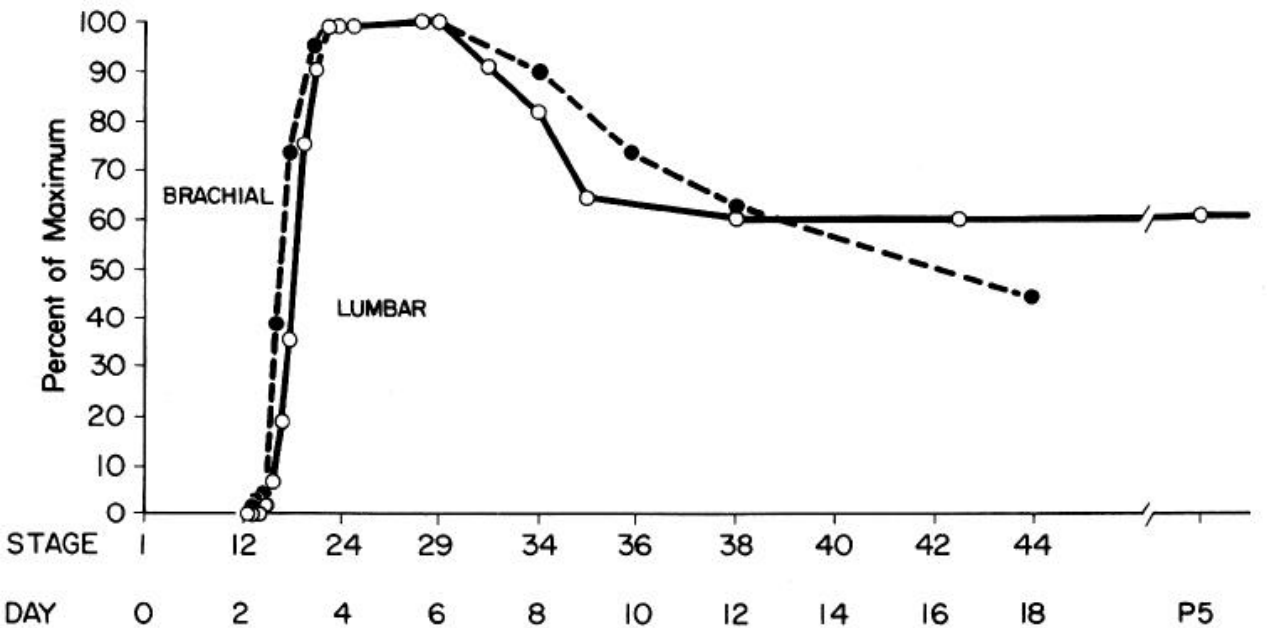




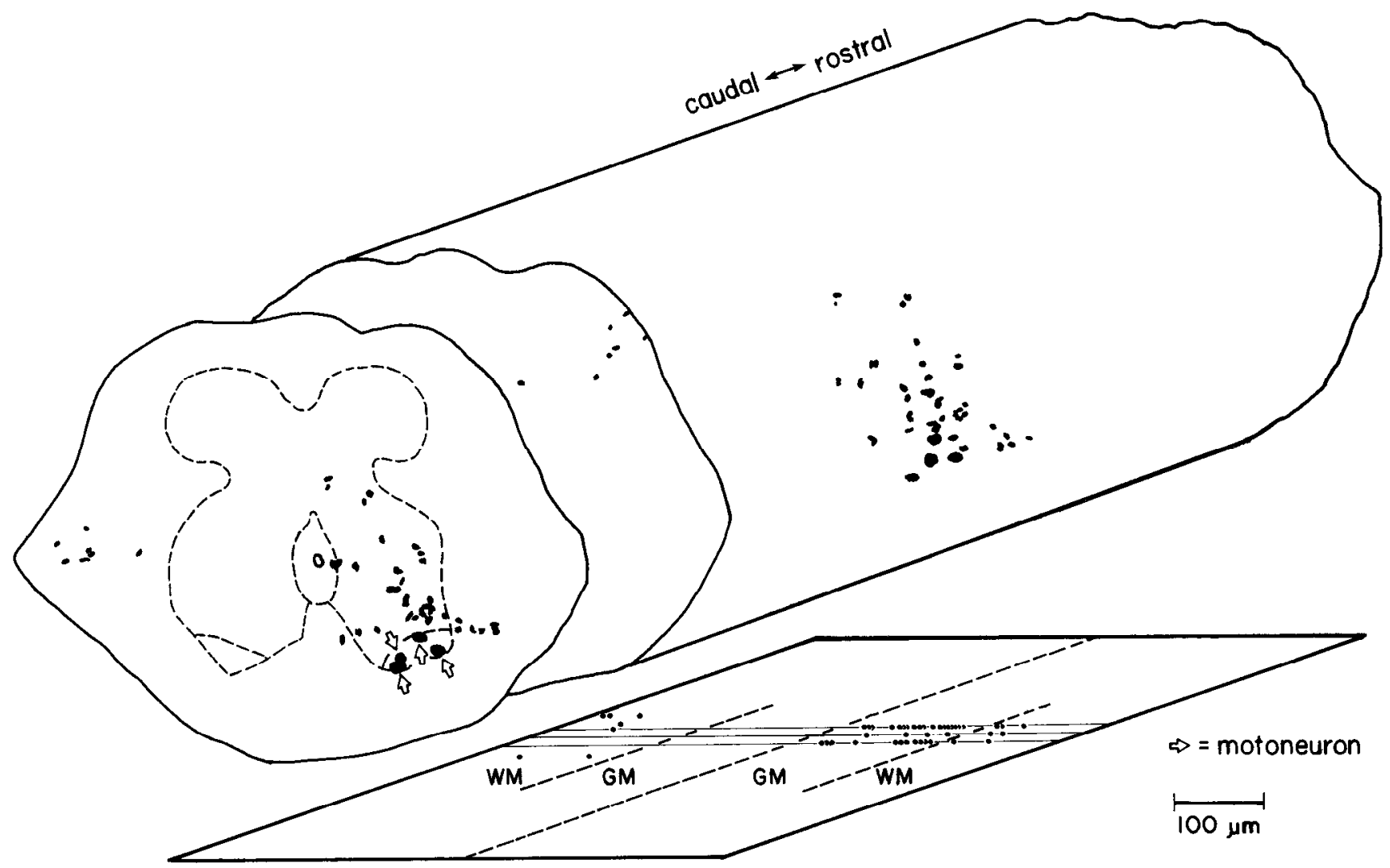

Figure 3. Planar arrangement of clonally related cells. An embryo was injected at stage 14 and killed at stage 39 . A segment-long piece of cervical spinal cord was reconstructed from serial $20 \mu \mathrm{m}$ sections. The position of each lacZ-positive cell in the 3-dimensional reconstruction (center) was then projected onto transverse (front) and horizontal (bottom) planes. This and subsequent reconstructions are oriented with the dorsal surface up. Four medial column MNs were labeled in this clone (arrows). All stained cells on the right side of the spinal cord were found within 3 sections (represented by the thin lines in the horizontal projection). The midline and the borders between gray matter $(G M)$ and white matter (WM) are marked by dashed lines. Contralateral cells were found only in the white matter and extended $160 \mu \mathrm{m}$ along the rostrocaudal axis. Scale bar, $100 \mu \mathrm{m}$.

embryo (see above) and because each spinal cord bore few clusters of lacZ-positive cells ( $<10$ in most cases), we believe that the cells comprising each cluster arose from a single infected cell and are therefore clonal relatives.

To obtain further evidence on this point, we performed an experiment of the sort described by Galileo et al. (1990). Embryos were injected with a mixture of 2 types of virus: LZ10, which encodes lacZ, and LZ12, which encodes a nuclear localization signal-lacZ fusion protein. When stained histochemically at stages 24-34, LZ10-infected cells have darkblue cytoplasm with unstained or lightly stained nuclei, whereas LZ12infected cells have dark-blue nuclei with unstained or lightly stained cytoplasm. [LZ12-infected cells are occasionally cytoplasmic lacZ-positive at stages 38 or later; see Galileo et al. (1990) for possible reasons.] If entire clusters were derived from one cell, some should be composed entirely of cytoplasmic lacZ-positive cells and others of nuclear lacZpositive cells. If, on the other hand, some clusters arose from 2 or more infected cells, some of these should contain a mixture of cytoplasmpositive and nucleus-positive cells. In a set of 20 stage 24-34 animals analyzed in this way, 13 clusters contained only cytoplasm-positive cells, 47 clusters contained only nucleus-positive cells, and no clusters contained both. By the chi-square test, the probability that $>20 \%$ of the clusters arose from more than one progenitor is $<0.05$.

Although we are confident that the vast majority of clusters of lacZpositive cells represent clones, it is possible that some clusters are not entire clones. Parts of some clones could have escaped analysis in any of 3 ways. First, 2 clusters were occasionally so close together that cells at their periphery could not be assigned with confidence to one cluster or the other. To avoid this uncertainty, we excluded from analysis clusters with centers spaced less than $200 \mu \mathrm{m}$ apart in stage $24-29$ animals and less than $300 \mu \mathrm{m}$ apart in stage $31-41$ animals. It is possible that these pairs of clusters actually comprised single clones, in which case we would have biased our sample against large clones. Second, clusters separated by more than $200-300 \mu \mathrm{m}$, which we considered separate clones, might have been part of a single clone in some cases. Finally, it is possible that some progeny of infected cells did not accumulate detectable levels of lacZ.

All 3 of these sources of error would, if they occurred, have had the same consequences: we would have underestimated the size of clones, the extent of their rostrocaudal spread, and the range of cell types within a clone. However, we have several reasons for believing that they do not seriously affect the conclusions we draw. First, because we found no restriction in the range of cell types within the clusters we did analyze (see below), our conclusions would be no different if some clusters were only parts of clones. Second, if separate clusters were parts of a single clone, it is most likely that each cluster would represent a subclone descended from one of the daughters of the originally infected progenitor. Our conclusions would then be valid for that subclone. Third, once we properly adjusted the number of virions injected, we needed to exclude few clusters $(<20 \%)$ from analysis because of their proximity to other clusters. Fourth, those clusters that were completely isolated (greater than $2 \mathrm{~mm}$ from other clusters) were representative of the total population analyzed in terms of cell number, rostrocaudal spread, and range of cell types.

\section{Results}

To label MNs and their relatives, we injected retroviral concentrate into the neural tube at stages 11-18. The first MNs leave the mitotic cycle at stage 15 in the brachial region and at stage 17 in the lumbar region (Fig. 2). Birth of MNs is nearly complete by stage 23 (Hollyday and Hamburger, 1977; M. Hol- 

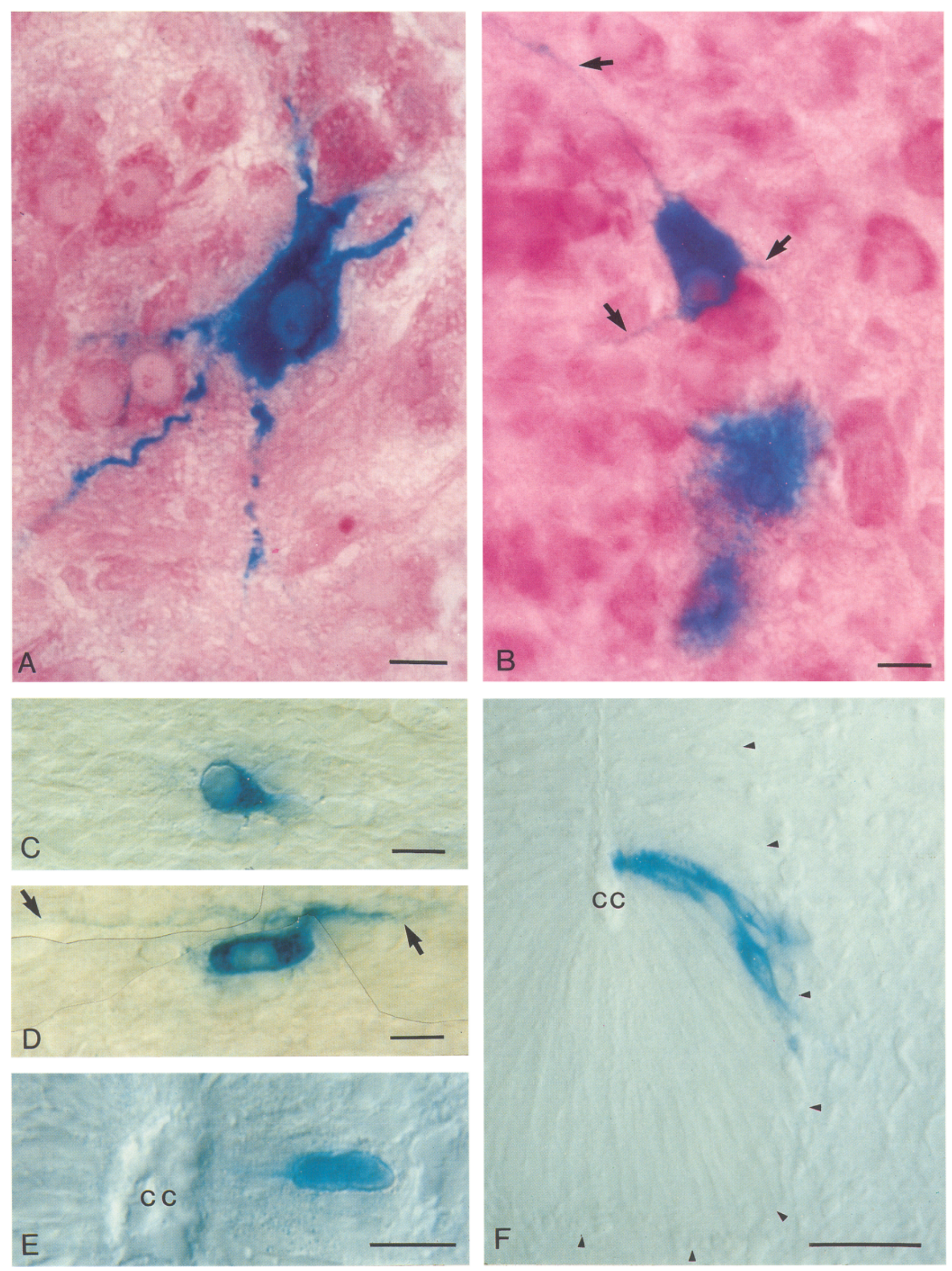


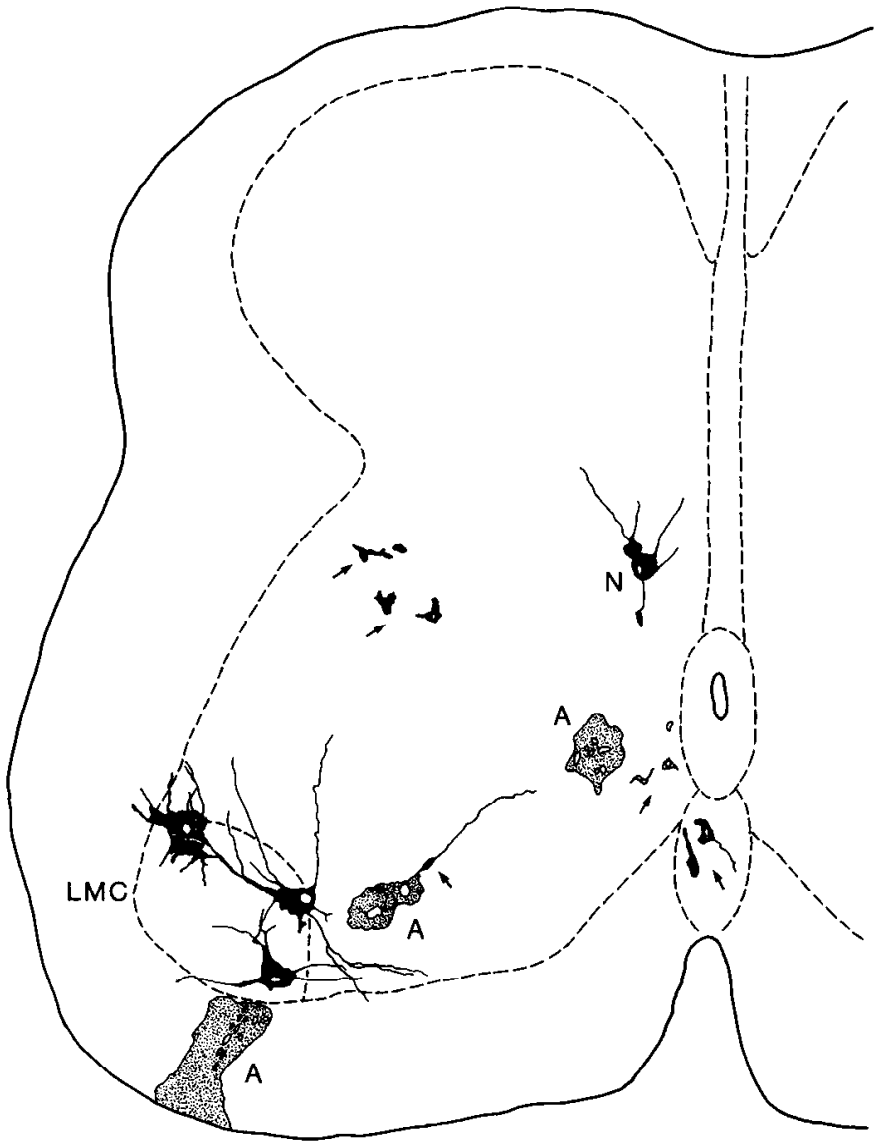

A

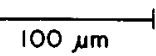

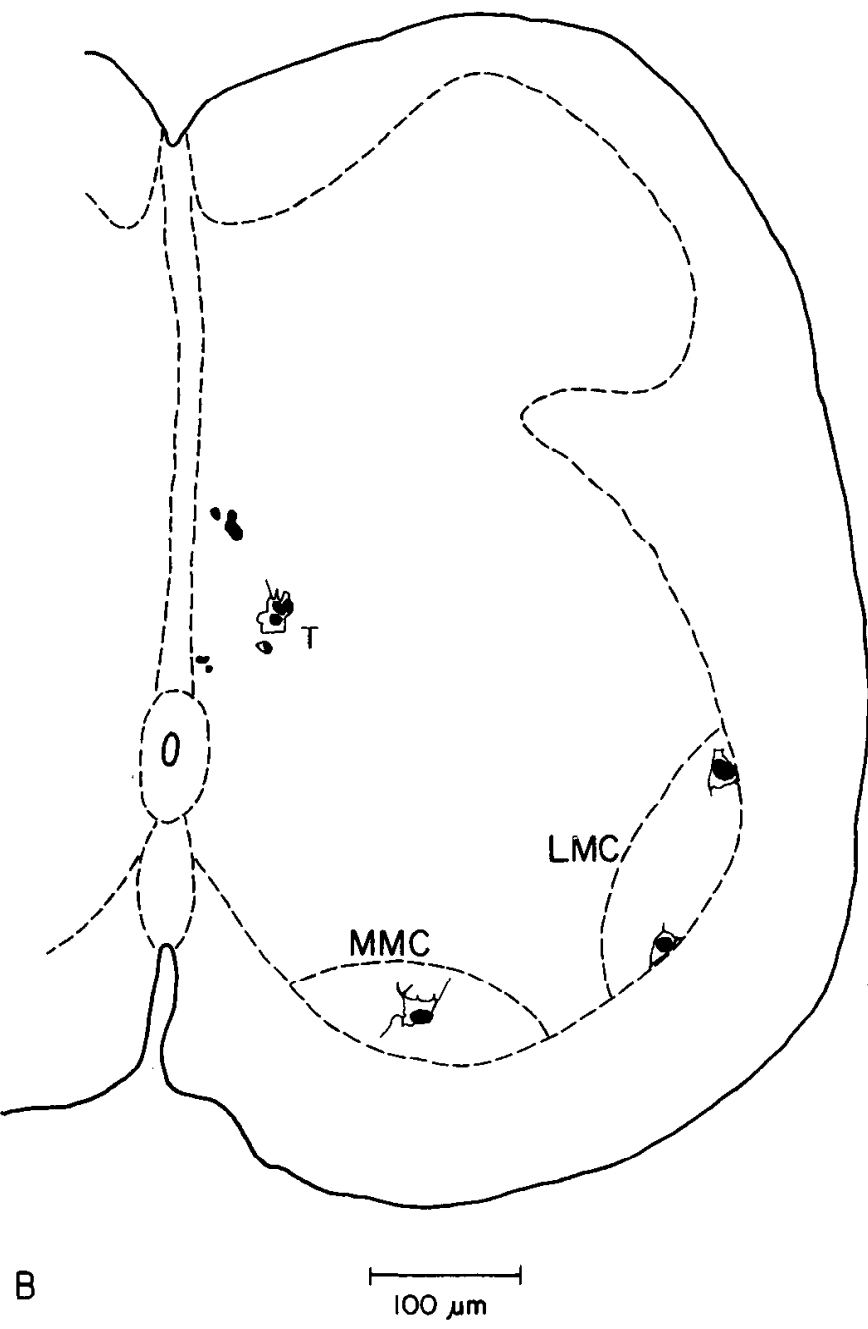

Figure 5. Camera lucida reconstructions of MN-containing clones at stage 40 . $A$, Caudal lumbar clone containing 3 MNs widely dispersed in the lateral motor column $(L M C)$. The virus was injected at stage 15. Another labeled neuron $(N)$ was seen more dorsomedially, perhaps in the rostral end of the sacral equivalent of the nucleus of Terni. Clusters of probable astrocytes $(A)$ and unidentified cells (arrows) were also stained. $B$, Caudal brachial spinal cord clone containing $2 \mathrm{MNs}$ in the lateral motor column (LMC) and 1 in the medial motor column (MMC), as well as 3 cells in the region of the column of Terni $(T)$. Other cells were present near the midline. Virus was injected at stage 13 . Because this embryo was injected with the LZ12 virus, staining was primarily nuclear and cytoplasmic morphology was indistinct.

lyday, personal communication). Therefore, our injection times ranged from before to just after the onset of MN birth. Motor axons leave the spinal cord by stage 17 , reach the base of the limb by stages $23-24$, and form functional connections by stages 27-28 (Landmesser and Morris, 1975; Lance-Jones and Landmesser, 1981; Hollyday, 1983; Bennett et al., 1988). Starting at stage 29 , approximately half of the MNs die; the majority of cell death is complete by stages 35-38 (Hamburger, 1975; Oppenheim and Majors-Willard, 1978; Lanser and Fallon, 1984; see Fig. 2). In our initial studies, spinal cords were fixed and stained at stages $38-41$, when the spinal cord is mature in many respects.

\section{Relatives of motoneurons}

LacZ-positive cells in the spinal cord occurred in discrete clusters (Fig. 1), each of which comprises the clonal progeny of a single infected cell. (The criteria for identifying clusters as clones are detailed in Materials and Methods.) Clones contained from 1 to a few hundred cells each and were found in all parts of the spinal cord. Multicellular clones usually formed radial or planar arrays, perpendicular to the ventricular and pial surfaces (e.g., Fig. 3, and see below). MNs in these clones were identified by their large size, characteristic shape, and location within the motor columns (Figs. 3, 4A, 5). Approximately $15 \%$ of all spinal

Figure 4. Identification of cell types. $A-C$ and $E$ are from stage $38-41$ embryos, $D$ from stage 45 , and $F$ from stage 34 . Animals in $A-D$ and $F$ were infected with LZ10, and $E$ with LZ12. $C C$, central canal. $A$, Lateral column MN. Scale bar, $10 \mu \mathrm{m}$. $B$, Neuron with processes (arrows) and 2 astrocytes. Scale bar, $20 \mu \mathrm{m}$. $C$, Probable oligodendrocyte (Nomarski optics). Scale bar, $10 \mu \mathrm{m}$. $D$, Probable oligodendrocyte (Nomarski optics). Photomontage of several different focal planes reveals longitudinal processes (arrows) extending from the cell body. Scale bar, $10 \mu \mathrm{m}$. $E$, Ependymal cell. Scale bar, $10 \mu \mathrm{m} . F$, Cells in the ventricular zone. Arrowheads indicate the outer edge of the ventricular zone. Scale bar, $50 \mu \mathrm{m}$. 


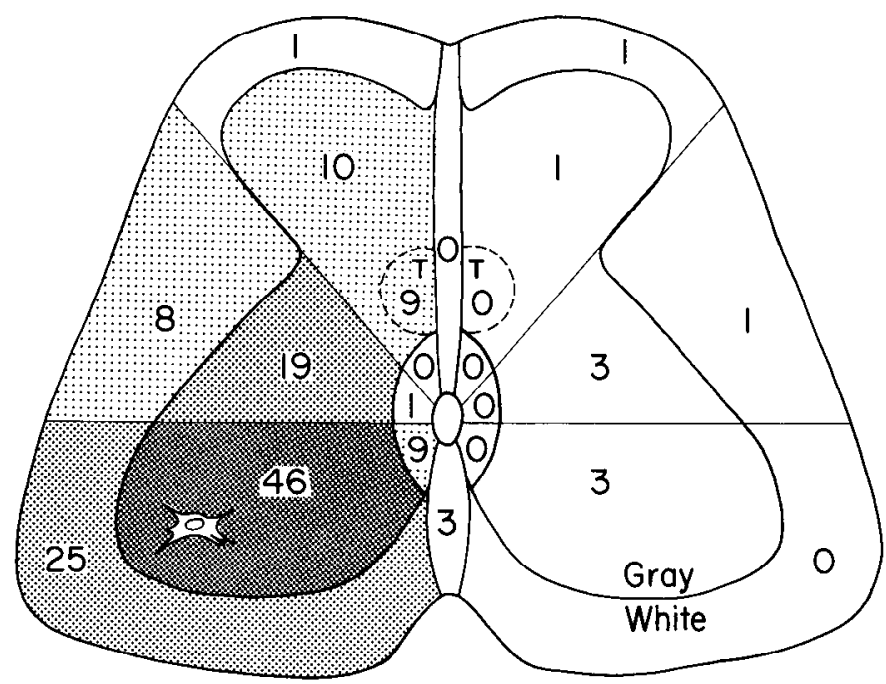

Figure 6. Distribution of cells other than MNs in MN-containing clones. The spinal cord was divided into ventral, intermediate, and dorsal regions, and into white matter, gray matter, and ependymal zones. The size of the ependyma has been exaggerated in the sketch for clarity. The region containing the labeled MNs is marked with the drawing of a soma. The column of Terni is labeled $T$. The numbers denote the percentage of $\mathrm{MN}$-containing clones with non-MNs in each region. Data are from 80 clones analyzed at stages $38-41$ and included both neurons and glia.

cord clones contained MNs. To study the range of cell types within clones and the arrangement of clonally related cells, we reconstructed $\mathrm{MN}$-containing clones from serial sections. Altogether, $80 \mathrm{MN}$-containing clones were reconstructed from 51 animals at stages 38-41. Twenty-five of these clones consisted of 1 lone $\mathrm{MN}$; the other 55 were multicellular.

In $82 \%(45 / 55)$ of the multicellular MN-containing clones, MNs had non-MN relatives. As detailed below, these non-MNs were found in both the gray and white matter and included other neurons, glia, and cells of the ependyma. We found no evidence for the occurrence of these cell types in specific combinations. Most MN relatives in both gray and white matter were located in the ventral part of the ipsilateral spinal cord but occasional cells were found dorsally or contralaterally (Fig. 6). These results suggest that the progenitors of most MNs are multipotential.

At least $55 \%$ of multicellular MN-containing clones contained other neurons, which were identified by their long processes, large nuclei, prominent nucleoli, and Nissl substance (Fig. 4B). These neurons were classified as interneurons or autonomic preganglionic neurons, based on their location. The interneurons possessed a variety of shapes and were found throughout the ventral and, less commonly, intermediate regions of the zona intermedia as well as in the ventromedially located nucleus of the anterior commissure (Matsushita, 1968), but not in the dorsal horn. Although most of the clonally related cells located contralateral to the MNs were probably glia, 2 clones had contralateral neurons. In contrast to the usual ventral location of MN relatives, labeled cells often were found in the column of Terni (Figs. 5, 6), which is populated by preganglionic autonomic neurons (Levi-Montalcini, 1950). Only once did we find an $\mathrm{MN}$ relative in the marginal paragriseal column of Hofmann, a cluster of neurons in the periphery of the white matter (Huber, 1936).

Forty-two percent of multicellular MN-containing clones contained cells in the white matter that were clearly glial, and many more also contained gray matter glia. Many of the glial cells in both gray and white matter were identifiable as astrocytes; they had somata that were smaller than those of neurons and that were surrounded by fine, feather-like processes (Fig. 4B). They were often found in large clusters with indistinct boundaries between cells and occasionally were associated with blood vessels. We tentatively identified a class of even smaller cells in the whitc matter as oligodendrocytes; these had scant but fairly distinctly demarcated cytoplasm, and occasionally extended short processes (Fig. 4C). They frequently occurred in longitudinal arrays that paralleled fiber tracts, and at later stages of development they bore multiple processes oriented parallel to the axons (Fig. $4 D$ ). In general, these cells were more widely dispersed along the rostrocaudal axis than their gray matter relatives (e.g., Fig. 3), and in some cases they extended several hundred microns from their apparent point of origin; such migratory behavior has been reported for oligodendrocytes and their precursors in other systems (e.g., Small et al., 1987; Gumpel et al., 1989). A few clones appeared to contain both astrocytes and oligodendrocytes. However, identification of immature glial cells based on morphology alone is uncertain, and more definitive studies will require a combination of lineage markers and cell type-specific antibody staining (e.g., Galileo et al., 1990).

Eighteen percent of multicellular MN-containing clones contained cells in the ependyma. These cells were usually radially oriented and columnar with elongated nuclei and processes that reached the central canal (Fig. 4, $E, F$ ); a few were larger cells with round nuclei and circumferentially oriented processes located just inside the outer margin of the ependyma. No MNcontaining clones contained roof plate cells, and only one had cells in the ventral midline of the ependyma. These cells extended processes to the pial surface and might represent remnants of the floor plate.

To determine whether progenitor cells infected at later stages give rise to a smaller range of cell types than do those infected earlier, we compared clones marked by injection at stages 11 and 17-18. As expected, clones labeled later contained fewer cells on average than clones labeled earlier. Clones labeled at stages $17-18$ had a mcan ( \pm SEM) of only $4.2 \pm 1.5$ cells per clone $(n=22)$ compared to $19.1 \pm 10.6$ after injections at stage $11(n=9)$. Clones consisting of only a single MN comprised $55 \%$ of the population following injection at stage $17-18$, but only $33 \%$ of the population following injection at stage 11 . The other, multicellular, clones frequently contained other interneurons, autonomic preganglionic neurons, glia, and/or ependymal cells following injection at either stage. None of the $10 \mathrm{multi}$ cellular MN-containing clones labeled at stages 17-18 consisted exclusively of MNs, and at least 5 of them contained glia. Thus, we have no evidence that MN progenitors are committed to generate MNs, or even neurons generally, shortly before the MNs are born (see Fig. 2).

\section{Motoneuron types}

Spinal MNs are aggregated into 2 elongated columns within the ventral horn. The medial motor column, which extends the length of the spinal cord, provides innervation for the axial musculature. MNs of the lateral motor column, which is found only in the brachial and lumbosacral expansions, project to limb muscles. Within each column, MNs innervating a given muscle are grouped into coherent, rostrocaudally elongated motor pools, each of which extends for up to several segments. In the chick, 


\begin{tabular}{|c|c|c|c|c|c|}
\hline \multirow[b]{2}{*}{ Stage } & \multicolumn{2}{|c|}{ Labeled MNs in } & \multicolumn{3}{|c|}{$\begin{array}{l}\text { Clones with } \geq 2 \mathrm{MNs} \\
\text { that have } \mathrm{MNs} \text { in }\end{array}$} \\
\hline & $\begin{array}{l}\mathrm{LMC} \\
(\%)\end{array}$ & $\begin{array}{l}\text { MMC } \\
(\%)\end{array}$ & $\begin{array}{l}\text { LMC only } \\
(\%[n])\end{array}$ & $\begin{array}{l}\text { MMC only } \\
(\%[n])\end{array}$ & $\begin{array}{l}\text { Both } \\
(\%[n])\end{array}$ \\
\hline $31-34$ & 90 & 10 & $85(71)$ & $0(0)$ & $15(29)$ \\
\hline $38-41$ & 89 & 11 & $80(71)$ & $0(2)$ & $20(27)$ \\
\hline
\end{tabular}

The percentage of labeled MNs was calculated from clones in lumbar and brachial segments; clones in thoracic and cervical segments, which have no lateral column, were not included. Animals were injected at stages $12-14$ and fixed at stages 31 34 (16 clones) or injected at stages 11-18 and fixed at stages 38-41 (47 clones) The numbers in parentheses represent the distribution of MNs predicted if each MN's location were independent of the position of other MNs in the same clone. For example, with $90 \%$ of MNs in the lateral motor column, by chance alone we would expect that $0.9^{n}$ of clones with $n$ MNs would have these MNs only in the lateral column. Values of $n$ here were taken from Figure 8 . The observed and predicted distributions do not differ significantly, nor do the distributions at the 2 stages $(p>0.1$ by the chi-square test).

limb muscles derived from the dorsal embryonic muscle mass are innervated by MNs in pools located in the lateral portion of the lateral motor column, while muscles from the ventral mass are innervated by MNs in the medial part of the lateral column (Landmesser, 1978; Hollyday, 1980). Thus, the position of an MN's soma in the spinal cord indicates the type of muscle to which that MN projects.

We frequently found clonally related MNs widely dispersed within the lateral motor column (Fig. $5 \mathrm{~A}$ ), indicating that they belonged to more than one motor pool. In some cases, MNs within a single clone populated both the medial and lateral margins of the lateral motor column (see, for example, Fig. $7 B$ ), implying that the target muscles can derive from both embryonic muscle masses. Thus MN progenitors can give rise to MNs that project to different muscles within a limb. More strikingly, MNs within a single clone were sometimes found in both the lateral and medial motor columns (Fig. $5 B$ ). This occurred in $20 \%$ of all brachial and lumbar clones containing $\geq 2 \mathrm{MNs}$ (Table 1). This percentage is lower than, but not significantly different from, the $27 \%$ expected by chance alone. If real, the difference could be due to a slight tendency for progenitors to produce one type of MN or might simply reflect a tendency for neighboring cells to follow a common migratory path. In either case, the presence of clonally related MNs in both columns implies that single progenitor cells labeled shortly before the time of $\mathrm{MN}$ birth can produce MNs that project to both axial and limb musculature.
In contrast to the extensive dispersal of clonally related MNs (and their relatives) in the transverse plane, the spread of MNs (and other neurons) along the rostrocaudal axis was strikingly limited. Within the gray matter, the mean $( \pm$ SEM) dispersal was $47 \pm 6 \mu \mathrm{m}$, with a maximum of $200 \mu \mathrm{m}$. The rostrocaudal restriction was evident after early as well as late injections, with a mean spread of $70 \pm 22 \mu \mathrm{m}$ in clones generated with stage 11 injections and $29 \pm 8 \mu \mathrm{m}$ after stage 17-18 injections. Spinal segments vary between 800 and $1700 \mu \mathrm{m}$ in length at these stages, depending on their rostrocaudal position. Thus, although segmental boundaries were not evident in our material, most clones were likely to be restricted to a single segment.

\section{Clones without motoneurons}

Approximately $85 \%$ of the lacZ-positive clones in the spinal cord did not contain MNs. These clones were not studied in detail, but a comparison of their more obvious features to those of the MN-containing clones was instructive. Some clones lacking MNs contained neurons in the ventral horn. These clones, like those containing MNs, had few neurons in the dorsal horn. Conversely, many clones contained neurons in the dorsal horn, but few of these had neurons in the ventral horn. Thus, separate populations of progenitors, possibly corresponding to the basal and alar plates (Hamburger, 1948; Wenger, 1950), appear to produce ventral and dorsal neurons.

On the other hand, clones containing and lacking MNs were similar in several respects: both were generally planar or radial in arrangement and were limited in their rostrocaudal spread. Many of these clones contained cells in both gray and white matter, and many contained both neurons and glia. These results suggest that similar types of progenitors produce both clones containing and clones lacking MNs.

\section{Motoneuron death and cell lineage}

MNs are born in excess of their final numbers. In the lumbar lateral motor column, approximately $40 \%$ die between stages 29 and 36 (Hamburger, 1975). MN death in the brachial lateral motor column is somewhat greater in both extent and duration, with approximately $40 \%$ of lateral motor column MNs dying by stages $38-41$ and $60 \%$ by stages $44-46$ (Oppenheim and Majors-Willard, 1978; Lanser and Fallon, 1984). MNs also die in the medial motor column, but the extent and timing of cell death in this region has been less extensively studied than in the lateral column (see Oppenheim et al., 1989). To learn how cell death affects clonally related cells, we analyzed clones from embryos killed before (stages 24-29) or during (stages 31-34)

Table 2. Number of cells per MN-containing clone increases between stages 31-34 and 38-41

\begin{tabular}{llll} 
& \multicolumn{2}{l}{ Stage at analysis } & $\begin{array}{l}\text { Significance } \\
\text { of difference }\end{array}$ \\
\cline { 2 - 3 } Area of spinal cord & $31-34$ & $38-41$ & $p>0.10$ \\
Gray matter (total) & $7.6 \pm 1.2$ & $10.9 \pm 2.4$ & $p=0.10$ \\
Gray matter (exclusive of MNs) & $4.6 \pm 1.8$ & $8.6 \pm 2.2$ & $p<0.05$ \\
White matter & $0.8 \pm 0.4$ & $6.1 \pm 2.6$ & $p>0.10$ \\
Ependyma & $\underline{1.3 \pm 0.4}$ & $\underline{0.7 \pm 0.3}$ & $p=0.07$ \\
Total & $9.6 \pm 1.6$ & $17.9 \pm 4.5$ & $p$
\end{tabular}

Cells in MN-containing clones were counted in embryos sacrificed at stages 31-34 (24 clones) or stages 38-41 (23 clones). To eliminate the time of injection as a variable, only clones labeled with injections at stages $12-14$ were analyzed. The data represent means \pm SEM. Significance was tested by Student's 2-tailed $t$-test. 


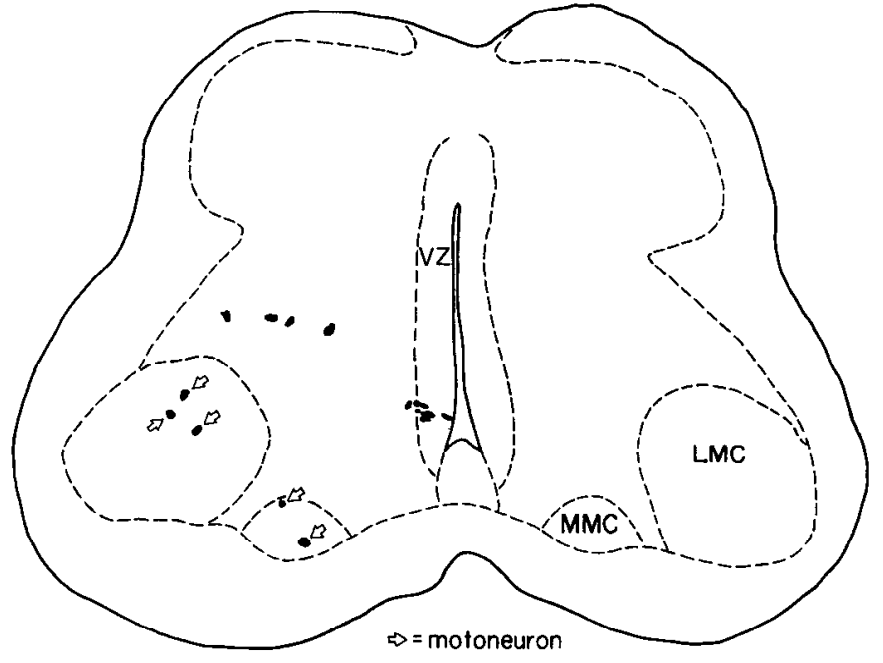

$A$
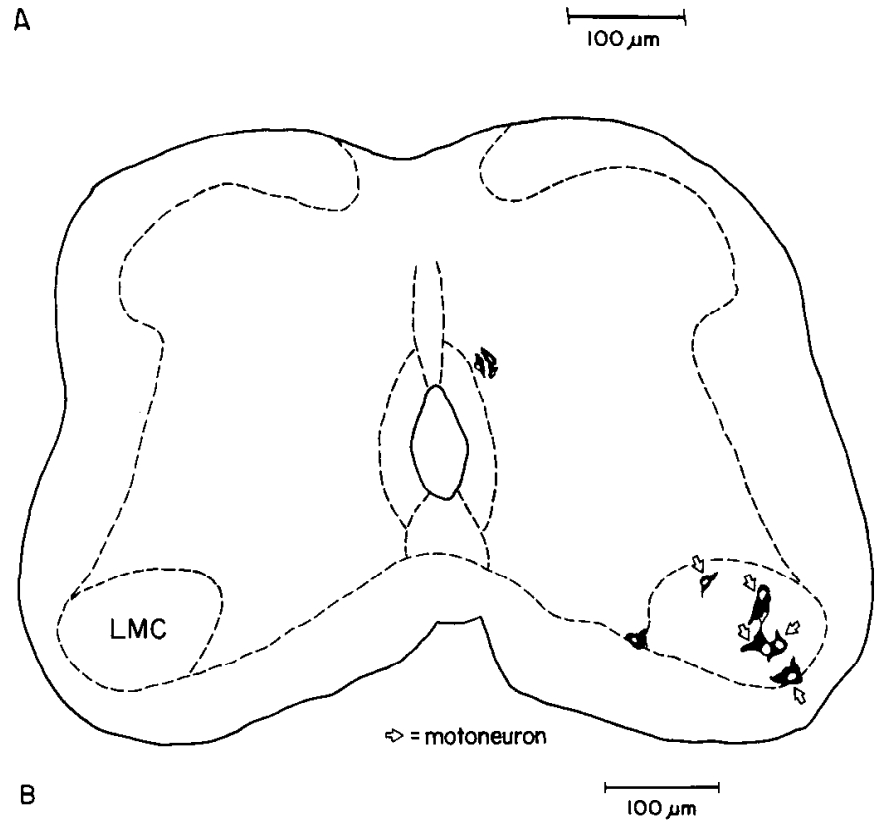

Figure 7. Camera lucida reconstructions of $\mathrm{MN}$-containing clones at stages 33-34. A, Brachial spinal cord clone containing $3 \mathrm{MNs}$ in the lateral motor column (LMC) and 2 in the medial motor column $(M M C)$, as well as cells in the ventricular zone (VZ) and forming gray matter. $B$. Rostral lumbar clone containing 5 MNs (open arrows) widely distributed within the lateral motor column. The cell just medial to the lateral motor column may be a medial column MN. The 3 small dorsomedial cells contained Nissl substance and probably lie within the nucleus of Terni; they are therefore likely to be autonomic preganglionic neurons.

the major period of $\mathrm{MN}$ death and compared them to clones from animals killed after most $\mathrm{MN}$ death has been completed (stages 38-41).

In spinal cords from younger animals, we again found discrete clusters of labeled cells. At stages 24-29, most clones consisted of radial streams of cells that extended from the ventricular zone toward the pia (see Fig. $4 F$ ). The cells from clones reconstructed at stages 31-34, like those from later stages, usually formed radial or planar arrays. The migratory paths that produce these patterns will be detailed elsewhere (Leber and Sanes, 1990). As at later stages, $\mathrm{MN}$-containing clones often contained non-MNs located in the gray matter, white matter, and ventricular zone (e.g., Fig. 7). The total number of cells of all types in MNcontaining clones did not decrease between stages 31-34 and 38-41. Instead, there was an increase which resulted largely from an increase in the number of white matter glial cells. Gray matter non-MNs, many of which were glia, also increased in number with age, whereas cells in the ventricular zone/ependyma showed a tendency to decrease in number (Table 2). Together, these results suggest that $\mathrm{MN}$ relatives are continuing to divide during the period when MNs are dying.

To ask whether the decision to live or die is made by individual cells or on a clonal basis, we counted the number of MNs per clone in animals killed at stages 24-29, 31-34, and 38-41. If all of the MNs in some clones died, but other clones were spared, cell death would result in a decrease in the number of $\mathrm{MN}$-containing clones but not in the number of surviving MNs per clone. On the other hand, if cell death were independent of lineage, we would expect approximately $40 \%$ fewer MNs per clone but little change in the number of clones. Although variability in the number of clones per animal made the change in this number difficult to analyze, it was feasible to determine the average number of MNs per clone. At all stages, MNs were readily identifiable by their size, shape, and position. At each stage, the total number of MNs varied from clone to clone, but the average number of MNs per clone decreased with time (Fig. 8; Table 3). This decrease contrasted with the overall increase in the total number of cells per clone (Table 2). We found no evidence that 2 discrete populations of clones, 1 with many MNs and 1 with few, existed or that the decrease in the mean number of MNs per clone resulted from a selective loss of the clones containing many MNs. Instead, the data were consistent with an average loss of $40 \%$ of MNs by each clone. Furthermore, the gradual decrease in the number of MNs per clone paralleled the decrease in total MN number (Table 3). These are the results expected if MN death is independent of lineage.

Finally, we compared the distribution of MNs before and after the completion of MN death. At stages 31-34, as at stages 3841 , clonally related $\mathrm{MNs}$ were not restricted to a single motor column (Fig. $7 A$ ) or pool (Fig. 7B). The percentage of brachial and lumbar clones containing $\geq 2$ MNs with MNs in both columns is similar at both ages (Table 1). These results suggest that cell death does not selectively affect specific subpopulations of MNs (for example, 1 column) and therefore is unlikely to restrict the range of targets of clonally related MNs.

\section{Discussion}

We have used recombinant retroviruses as markers to answer 3 sets of questions about the lineage of MNs. What are the close relatives of the MN? How widely dispersed are clonally related MNs? How does naturally occurring cell death affect clones of MNs?

\section{Lineage}

Little is known about the time at which cells in the developing spinal cord become committed to their eventual fates. At one extreme, lineage might be totally indeterminate, with every precursor cell having the potential to give rise to any cell type. Alternatively, some degree of commitment might arise, perhaps leading to a progressive restriction in the range of cell types that a progenitor can produce. For example, an $\mathrm{MN}$ projecting to a particular muscle could arise from a cell that produced MNs projecting to other muscles as well. This cell, in turn, might have arisen from a cell that also generated other types of cho- 
linergic neurons, which arose from a cell that gave rise to multiple types of neurons, which arose from a cell that produced glia as well.

To distinguish among these and other patterns, we compared the range of cell types that arose from retrovirally marked precursors in the chicken spinal cord. Our results are most consistent with an indeterminate lineage pattern: injections at stages 11-18 labeled clones containing not only MNs, but also a variety of other types of neurons as well as glia. The diversity of cell types within such clones argues against the existence of dedicated "motoneuroblasts" from which MNs arise. It is particularly noteworthy that MNs had interneurons and glia as relatives even when the virus was injected at stages $17-18$, only 1 or 2 cell cycles before all MNs are born (Hollyday and Hamburger, 1977; Stern et al., 1988; M. Hollyday, personal communication). Although the existence of occasional clones containing only MNs suggested that a few neuroepithelial cells could have been committed to produce only MNs, we suspect that these clones arose by chance from uncommitted precursors or because of migrational constraints and not because of specific, determinate lineages. We therefore conclude that spinal progenitors are not restricted to an exclusively motoneuronal pathway even as late as 1-2 generations before $\mathrm{MN}$ birth.

About half of the MN-containing clones we analyzed included glia. These glia were found in both the gray and white matter. They certainly included astrocytes and probably included oligodendrocytes as well; however, oligodendrocytes cannot be definitively distinguished from white matter astrocytes and glial precursors without ultrastructural or immunohistochemical criteria (see Miller et al., 1985; Hirano and Goldman, 1988). The presence of neurons and glia in the same clone is consistent with similar findings in the chicken optic tectum (Gray et al., 1988; Galileo et al., 1990), forebrain (Gray and Sanes, 1989), and dorsal root ganglion (Frank and Sanes, 1989), and in rat and frog retina (Turner and Cepko, 1987; Holt et al., 1988; Wetts and Fraser, 1988), but differs from the rodent cerebral cortex, in which neurons and astrocytes are not found in the same clones (Luskin et al., 1988; Price and Thurlow, 1988). The spinal cord apparently resembles retina in that the terminal few divisions that generate postmitotic MNs can also generate glial cells or glial precursors. However, infection at later stages will be required to determine whether interneuronal and glial lincages eventually diverge.

Although cells closely related to MNs were diverse in phenotype, their spatial distribution was restricted. Most were found in the ventral and intermediate regions on one side of the spinal cord, and only a few were dorsal or contralateral. The relative
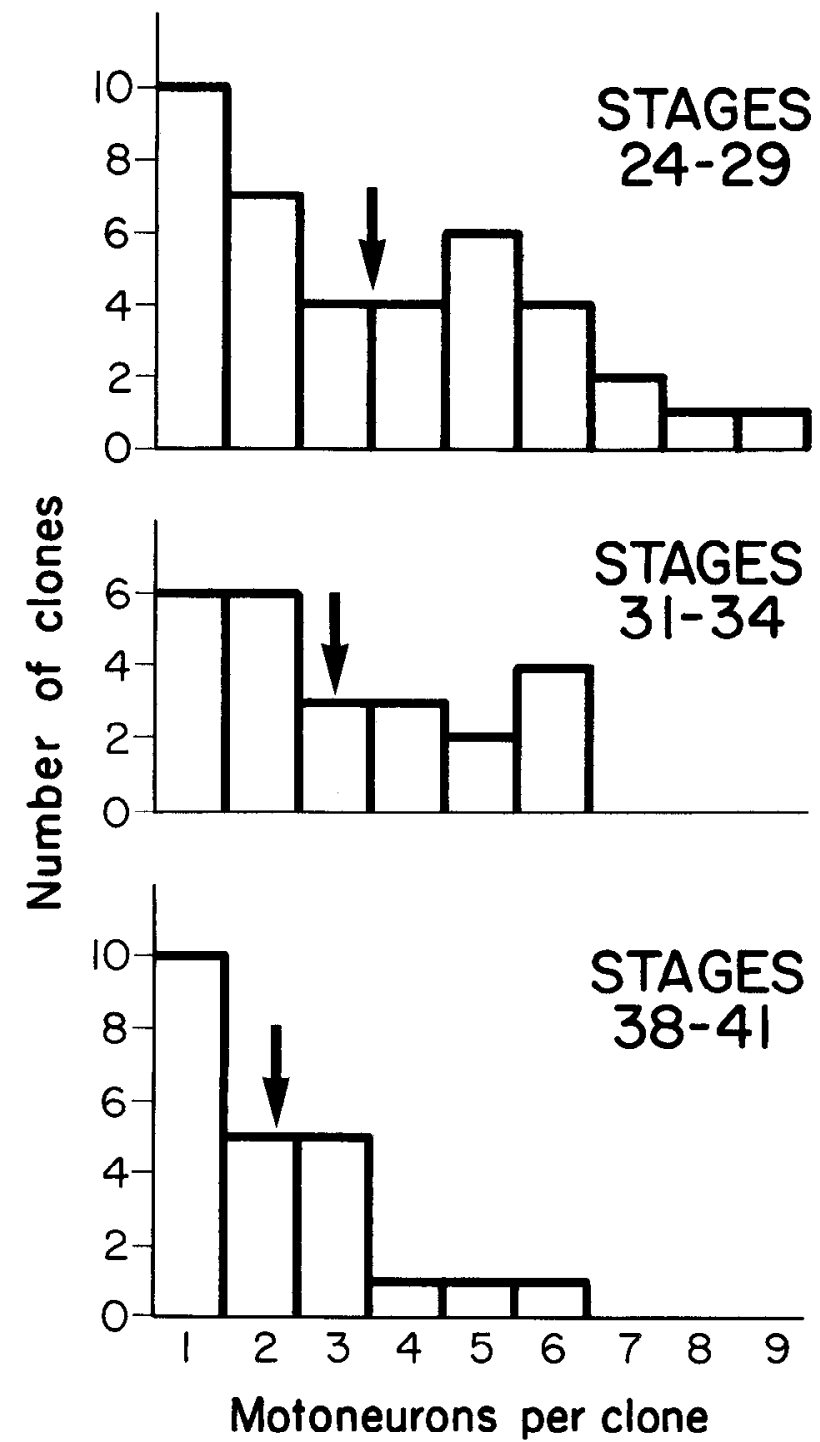

Figure 8. Histogram showing the number of MNs per clone at 3 stages of development. Embryos were injected at stages 12-14 and sacrificed at the times indicated: before (stages 24-29), during (stages 31-34), and after (stages 38-41) the major period of MN death. The means are marked by arrows.

restriction of cells within clones to either dorsal or ventral quadrants was also seen in clones lacking MNs. This distribution provides novel evidence for previous suggestions that dorsal and ventral neurons derive from distinct portions of the neu-

Table 3. Total number of MNs and number of MNs per clone decline in parallel

\begin{tabular}{llll} 
& \multicolumn{2}{l}{ Number of MNs } & \multicolumn{2}{l}{$\begin{array}{l}\text { Number of MNs per } \\
\text { Stage }\end{array}$} & Brachial LMC & Lumbar LMC & (mean \pm SEM) \\
\hline $24-29$ & $14,900(100 \%)$ & $20,180(100 \%)$ & $3.5 \pm 0.4(100 \%)(n=39)$ \\
$31-34$ & $13,450(90 \%)$ & $17,205(85 \%)$ & $3.0 \pm 0.4 \quad(87 \%)(n=24)$ \\
$38-41$ & $9320(63 \%)$ & $12,275(61 \%)$ & $2.2 \pm 0.3 \quad(62 \%)(n=23)$
\end{tabular}

Number of MNs per clone before, during, and after the major period of MN death compared with MN population size. The numbers of MNs in the brachial and lumbar lateral motor columns are extrapolated from data in Lanser and Fallon (1984) and Hamburger (1975), respectively. Values for the number of MNs per clone are taken from Figure 8. The numbers in parentheses are percentages of the values at stages $24-29$, which are known to precede MN death. The mean number of MNs per clone differs between stages $24-29$ and $38-41$ and between stages $31-34$ and $38-41 ; p<0.05$ by Student's 1 -tailed $t$-test. $L M C$, lateral motor column. 
roepithelium, the alar and basal plates, respectivcly (Hamburger, 1948; Wenger, 1950). However, this restriction is not absolute, and it could arise either from migratory constraints on postmitotic neurons or from some degree of lineage restriction; our results do not permit us to distinguish these possibilities.

The single major exception to the concentration of $\mathrm{MN}$ relatives in the ventral horn was the disproportionate number of cells in the column of Terni, a dorsomedially located nucleus of autonomic preganglionic neurons. The frequent presence of these neurons in $\mathrm{MN}$-containing clones is explained by their unusual developmental history: they originate ventrally and begin to differentiate near the ventral horn MNs, but then undergo a secondary dorsomedial migration (Levi-Montalcini, 1950). Thus, the previously hypothesized close relationship of autonomic preganglionic neurons to somatic MNs is supported by their coexistence in many clones.

MNs are among the first cells born in the spinal cord (Langman and Haden, 1970). The presence of other cell types in MNcontaining clones implies that entire clones do not leave the cell cycle simultaneously. Two additional pieces of evidence support the conclusion that clonal relatives of MNs remain mitotically active after MNs are born. First, many MN relatives remain in the germinal (ventricular) zone at stages 31-34. Second, the number of cells per clone in both the white and gray matter increases between stages 31-34 and 38-41 despite the fact that some MNs die during this interval. Thus, it seems likely that some progenitors divide to produce an $\mathrm{MN}$ plus another progenitor that then divides again to produce other cell types. Perhaps the time at which a cell becomes postmitotic, or the local environment present at the time, influences the decision of a newborn cell to become an $\mathrm{MN}$; such factors have been postulated to explain the relationship between birth date and laminar position for neurons in the mammalian cerebral cortex (reviewed in McConnell, 1988).

\section{Motoneuron types}

Studies on the outgrowth of motor axons suggest that MNs are specified as members of particular pools prior to and independent of contact with their targets (reviewed in Landmesser, 1988). In principle, lineage could contribute to determining this identity; for example, MNs descended from a single progenitor might he restricted to a single motor pool. This restriction could occur even though, as shown above, MN progenitors also produce other cell types. It is clear that individual motor pools in mice derive from more than 1 progenitor (Herrup et al., 1984; Vogel et al., 1988). However, whether individual progenitors in the neural tube contribute to more than 1 pool was not hitherto known.

We found that clonally related MNs can be located in multiple pools, in both the lateral and medial portions of the lateral motor column, and in both the lateral and medial motor columns. Based on extirpation experiments, Wenger (1950) suggested that separate regions of the neuroepithelium generated the medial and lateral motor columns; our results do not support this notion. Instead, we conclude that individual progenitors are not committed to produce MNs specified to project to specific muscles, to muscles derived from particular muscle masses, or even to axial as compared with limb musculature. Although complicated lineage-based schemes cannot be excluded, our results point to epigenetic factors as prime determinants of the membership of MNs in particular pools or columns.

In contrast, we do observe a striking rostrocaudal restriction in the distribution of clonally related MNs. This restriction is noteworthy in light of studies suggesting that the rostrocaudal axes of spinal motor pools are mapped systematically onto the rostrocaudal axes of their target muscles during development (Brown and Booth, 1983; Bennett and Lavidis, 1984; Fetchko, 1987; Laskowski and Sanes, 1987) and that motor axons display preferences for positionally matched targets during regeneration (Wigston and Kennedy, 1987; Laskowski and Sanes, 1988). Autonomic preganglionic neurons are also positionally matched to their peripheral targets during development (Langley, 1892; $\mathrm{Njå} \mathrm{and} \mathrm{Purves,} \mathrm{1977)} \mathrm{and} \mathrm{following} \mathrm{regeneration} \mathrm{(Purves} \mathrm{et}$ al., 1981; Wigston and Sanes, 1982); correspondingly, clonally related cells in the column of Terni were as rostrocaudally restricted as somatic MNs, despite their extensive ventrodorsal migration. The structural basis for the restricted rostrocaudal dispersal remains to be determined; it may be related to factors that constrain early arising intraspinal axons to project primarily in the transverse plane (Holley, 1982; Holley et al., 1982). Whatever its basis, however, the rostrocaudal restriction of clonally related cells indicates that cells arising from a single progenitor in the neuroepithelium come to lie in a narrow corresponding plane in the gray matter. In schemes attempting to explain how positional information influences development, it is commonly supposed that cells acquire positional values before they differentiate and perhaps before their final mitoses. If such schemes are valid, our results imply that cells assigned a common value during development would come to share rostrocaudal positions in maturity.

The restriction of clonally related MNs to subclasses that are positionally defined raises the question as to whether lineage is important in the establishment of other MN subclasses. For example, subsets of MNs are immunoreactive for the calcitonin gene-related peptide, somatostatin, or vasoactive intestinal polypeptide (e.g., Villar et al., 1989). Other MN subclasses include fast and slow, alpha and gamma, flexor and extensor, and large and small. Whether single precursors give rise to MNs in each of these subclasses remains to be explored.

\section{Motoneuron death}

There exists abundant evidence that a large fraction of spinal MNs die during normal development and that an MN's survival is largely dependent on extrinsic determinants, such as limited access to peripheral trophic factors (Hamburger and Oppenheim, 1982). However, this evidence does not a priori rule out the possibility that a cell's lineage influences its chance of survival: for example, MNs in different clones could vary in their requirements for or ability to accumulate a trophic factor. Indeed, Mattson et al. (1989) have recently shown that lineage influences the susceptibility of cultured central neurons to the lethal effects of an excitotoxin. To test for an influence of lineage on $\mathrm{MN}$ survival in ovo, we determined the average number of MNs per clone at times before, during, and after the major period of naturally occurring $\mathrm{MN}$ death and compared these values to published data on the total number of MNs. This analysis does not test for a genealogy like that of Caenorhabditis elegans (Sulston et al., 1983) in which specific, individual MNs in many clones are fated to die; however, this type of pattern is extremely unlikely given all the evidence for indeterminate lineage. We found that the number of MNs per clone declined in precise parallel with the total $\mathrm{MN}$ population size. This result implies that a MN's decision to live or die does not depend on its genealogy. 


\section{References}

Altman J, Bayer SA (1984) The development of the rat spinal cord. Adv Anat Embryol Cell Biol 85:1-166.

Bennett GS, Hollander BA, Laskowska D (1988) Expression and phosphorylation of the mid-sized neurofilament protein NF-M during chick spinal cord neurogenesis. J Neurosci Res 21:376-390.

Bennett MR, Lavidis NA (1984) Development of the topographic projection of motor neurons to a rat muscle accompanies loss of polyneuronal innervation. J Neurosci 4:2204-2212.

Brown MC, Booth CM (1983) Postnatal development of the adult pattern of motor axon distribution in rat muscle. Nature 304:741742.

Fetchko JR (1987) A review of the organization and evolution of motoneurons innervating the axial musculature of vertebrates. Brain Res Rev 12:243-280.

Frank E, Sanes JR (1989) Cell lineage in chick sensory ganglia studied with a retroviral marker. Soc Neurosci Abstr 15:600.

Galileo DS, Gray GE, Owens GC, Majors J, Sanes JR (1990) Neurons and glia arise from a common progenitor in chick optic tectum: demonstration with two retroviruses and cell type-specific antibodies. Proc Natl Acad Sci USA 87:458-462.

Gray GE, Sanes JR (1989) Migratory patterns of clonally related cells differ in chicken tectum and forebrain. Soc Neurosci Abstr 15:598.

Gray GE, Glover JC, Majors J, Sanes JR (1988) Radial arrangement of clonally related cells in the chicken optic tectum: lineage analysis with a recombinant retrovirus. Proc Natl Acad Sci USA 85:73567360.

Gumpel M, Gout O, Lubetzki C, Gansmuller A, Baumann N (1989) Myelination and remyelination in the central nervous system by transplanted oligodendrocytes using the shiverer model. Discussion on the remyelinating cell population in adult mammals. Dev Neurosci 11: $132-139$.

Hamburger, V (1948) The mitotic patterns in the spinal cord of the chick embryo and their relation to histogenetic processes. J Comp Neurol 88:221-284.

Hamburger V (1975) Cell death in the development of the lateral motor column of the chick embryo. J Comp Neurol 160:535-546.

Hamburger V (1977) The developmental history of the motor neuron. Neurosci Res Prog Bull 15(Suppl):1-37.

Hamburger V, Hamilton $H$ (1951) A series of normal stages in the development of the chick embryo. J Morphol 88:49-92.

Hamburger V, Oppenheim RW (1982) Naturally occurring neuronal death in vertebrates. Neurosci Comment 1:39-55.

Herrup K, Diglio TJ, Letsou A (1984) Cell lineage relationships in the development of the mammalian CNS. I. The facial nerve nucleus. Dev Biol 103:329-336.

Hirano M, Goldman JE (1988) Gliogenesis in rat spinal cord: evidence for origin of astrocytes and oligodendrocytes from radial precursors. J Neurosci Res 21:155-167.

Holley JA (1982) Early development of the circumferential axonal pathway in mouse and chicken spinal cord. J Comp Neurol 205:371382

Holley IA, Nornes HO, Morita M (1982) Guidance of neuritic growth in the transverse plane of embryonic mouse spinal cord. J Comp Neurol 205:360-370.

Hollyday M (1980) Motoneuron histogenesis and the development of limb innervation. Curr Top Dev Biol 15:181-215.

Hollyday M (1983) Development of motor innervation of chick limbs. In: Limb development and regeneration, part A (Fallon JR, Caplan AI, eds), pp 183-193. New York: Liss.

Hollyday M, Hamburger V (1977) An autoradiographic study of the formation of the lateral motor column in the chick embryo. Brain Res 132:197-208

Holt CE, Bertsch TW, Ellis HM, Harris WA (1988) Cellular determination in the Xenopus retina is independent of lineage and birth date. Neuron 1:15-26.

Huber IF (1936) Nerve roots and nuclear groups in the spinal cord of the pigeon. J Comp Neurol 65:43-91.

Lance-Jones C, Landmesser L (1981) Pathway selection by chick lumbosacral motoneurons during normal development. Proc R Soc Lond B 214:1-18.

Landmesser L (1978) The distribution of motoneurons supplying chick hind limb muscles. J Physiol (Lond) 284:371-389.

Landmesser L (1980) The generation of neuromuscular specificity. Annu Rev Neurosci 3:279-302.
Landmesser L (1988) Peripheral guidance cues and the formation of specific motor projections in the chick. In: From message to mind (Easter SS Jr, Barald KF, Carlson BM, eds), pp 121-133. Sunderland, MA: Sinauer.

Landmesser L, Morris DG (1975) The development of functional innervation in the hindlimb of the chick embryo. I Physiol (Lond) 249:301-326.

Langley JN (1892) On the origin from the spinal cord of the cervical and upper thoracic sympathetic fibres, with some observations on white and grey rami communicantes. Phil Trans R Soc Lond (Biol) 183:85-124.

Langman J, Haden CC (1970) Formation and migration of neuroblasts in the spinal cord of the chick embryo. J Comp Neurol 138:419-432.

Lanser ME, Fallon JF (1984) Development of the lateral motor column in the limbless mutant chick embryo. J Neurosci 4:2043-2050.

Laskowski MB, Sanes JR (1987) Topographic mapping of motor pools onto skeletal muscles. J Neurosci 7:252-260.

Laskowski MB, Sanes JR (1988) Topographically selective reinnervation of adult mammalian skeletal muscles. J Neurosci 8:3094-3099.

Leber SM, Sanes JR (1990) Migration of clonally related cells in developing chick spinal cord. Soc Neurosci Abstr 16 (in press).

Leber SM, Breedlove SM, Sanes JR (1989a) Lineage of motoneurons in chick spinal cord studied with a retroviral marker. Soc Neurosci Abstr 15:600.

Leber SM, Breedlove SM, Sanes JR (1989b) Lineage of motoneurons in chick spinal cord studied with a retroviral marker. Ann Neurol 26: 447-448.

Levi-Montalcini R (1950) The origin and development of the visceral system in the spinal cord of the chick embryo. J Morphol 86:253283.

Luskin MB, Pearlman AL, Sanes JR (1988) Cell lineage in the cerebral cortex of the mouse studied in vivo and in vitro with a recombinant retrovirus. Neuron 1:635-647.

Matsushita M (1968) Zur Zytoarchitektonik des Hühnerrückenmarkes nach Silberimprägnation. Acta Anat 70:238-259.

Mattson MP, Guthrie PB, Hayes BC, Kater SB (1989) Roles for mitotic history in the generation and regeneration of hippocampal neuroarchitecture. J Neurosci 9:1223-1232.

McConnell SK (1988) Development and decision-making in the mammalian cerebral cortex. Brain Res Rev 13:1-23.

Miller AD, Buttimore C (1986) Redesign of retrovirus packaging cell lines to avoid recombination leading to helper virus production. Mol Cell Biol 6:2895-2902.

Miller RH, David S, Patel R, Abney ER, Raff MC (1985) A quantitative immunohistochemical study of macroglial cell development in the rat optic nerve: in vivo evidence for two distinct glial cell lineages. Dev Biol 111:35-41.

Njå A, Purves D (1977) Specific innervation of guinea-pig superior cervical ganglion cells by preganglionic fibres arising from different levels of the spinal cord. J Physiol (Lond) 264:565-583.

Oppenheim RW (1989) The neurotrophic theory and naturally occurring motoneuron death. Trends Neurosci 12:252-255.

Oppenheim RW, Majors-Willard C (1978) Neuronal cell death in the brachial spinal cord of the chick is unrelated to the loss of polyneuronal innervation in wing muscle. Brain Res 154:148-152.

Oppenheim RW, Cole T, Prevette D (1989) Early regional variations in motoneuron numbers arise by differential proliferation in the chick spinal cord. Dev Biol 133:468-474.

Price J, Thurlow L (1988) Cell lineage in the rat cerebral cortex: a study using retroviral-mediated gene transfer. Development 104:473482.

Purves D, Thompson W, Yip JW (1981) Reinnervation of ganglia transplanted to the neck from different levels of the guinea-pig sympathetic chain. J Physiol (Lond) 313:49-63.

Ramón y Cajal S (1960) Studies on vertebrate neurogenesis (Guth L, trans), $432 \mathrm{pp}$. Springfield, IL: Thomas. Etudes sur la neurogenèsis de quelques vertébrés (1929).

Sanes JR (1989) Analysing cell lineage with a recombinant retrovirus. Trends Neurosci 12:21-28.

Sanes JR, Rubinstein JLR, Nicolas J-F (1986) Use of a recombinant retrovirus to study post-implantation cell lineage in mouse embryos. EMBO J 5:3133-3142.

Small RK, Riddle P, Noble M (1987) Evidence for migration of oligodendrocyte-type- 2 astrocyte progenitor cells into the developing rat optic nerve. Nature 328:155-157. 
Stern CD, Fraser SE, Keynes RJ, Primmett DRN (1988) A cell lineage analysis of segmentation in the chick embryo. Development 104(Suppl): 231-244.

Sulston JE, Schrierenberg E, White JG, Thomson JN (1983) The embryonic cell lineage of the nematode Caenorhabditis elegans. Dev Biol 100:64-119.

Turner DL, Cepko CL (1987) A common progenitor for neurons and glia persists in rat retina late in development. Nature 328:131-136.

Villar MJ, Roa M, Huchet M, Hökfelt T, Changeux J-P, Fahrenkrug J, Brown JC, Epstein M, Hersh L (1989) Immunoreactive calcitonin gene-related peptide, vasoactive intestinal polypeptide, and somatostatin in developing chicken spinal cord motoneurons. Distribution and role in regulation of cAMP in cultured muscle cells. Eur J Neurosci $1: 269-287$.
Vogel MW, English AW, Herrup K (1988) Chimeric analysis of lineage relationship among mouse lumbar motoneurons. Soc Neurosci Abstr 14:1130.

Wenger EL (1950) An experimental analysis of relations between parts of the brachial spinal cord of the embryonic chick. J Exp Zool 114: 51-91.

Wetts R, Fraser SE (1988) Multipotent precursors can give rise to all major cell types of the frog retina. Science 239:1142-1145.

Wigston DJ, Kennedy PR (1987) Selective reinnervation of adult transplanted muscles by their original motoneurons in the axolotl. $\mathrm{J}$ Neurosci 7:1857-1865.

Wigston DJ, Sanes JR (1982) Selective reinnervation of adult mammalian muscle by axons from different segmental levels. Nature 299: 464-467. 